\title{
THE CASE OF ROBERT LATIMER: A Commentary on Crime and Punishment
}

\author{
Barney Sneiderman
}

\begin{abstract}
My object most sublime 1 shall achieve in time
To make the punishment fit the crime.
\end{abstract}

Gilbert and Sullivan, "The Mikado"

\section{NOTE TO THE READER}

This paper is about the sentencing of Robert Latimer, a Saskatchewan farmer convicted of second-degree murder for the killing of his severely disabled twelve-yearold daughter. As it now stands, he is facing life imprisonment and will not be eligible for parole until he has served ten years. I do not discuss the facts of the case (except insofar as they address Latimer's motive) as the reader will undoubtedly have a general familiarity with the events surrounding the death of Tracy Latimer. That is because the case has been intermittently in the news for the last six years; 1 doubt that any Canadian courtroom drama has attracted more media attention and public interest than this "mercy-killing" case. But since I do not even mention Robert Latimer until the sixth page, I owe it to the reader to explain my approach to the subject.

First, for reasons explained in due course, I begin by presenting the perspective of those in the disabled community - by which I mean the disabled themselves and their caregivers, often the parents - who oppose leniency for Latimer. As one such member of that community has said, the Latimer case cannot be viewed in isolation from various health care issues of concern to the disabled; for that reason I believe it necessary to place that perspective in a context.

Once that is in place, I then turn to Robert Latimer and present the case against his current sentence. $I$ do so by a critique of the principles of punishment that address his case and also by rejecting the policy of mandatory minimum sentencing for murder.

I look upon this paper as an essay, not as an analysis of the legal issues that will be considered by the Supreme Court some time next year. Thus, for example, I make no effort to analyze the conflicting views of the trial judge in the second trial and the Saskatchewan Court of Appeal on the question of a constitutional exemption to the mandatory minimum sentence for murder.

Professor, Faculty of Law, University of Manitoba, Winnipeg, Manitoba. I would like to thank the following for their helpful comments on the penultimate draft of this paper: Professors Trevor Anderson, Cameron Harvey, and Bryan Schwartz, Faculty of Law, University of Manitoba; Professor Michael Feld, Department of Philosophy, University of Manitoba; a trio of lawyers and former students of mine - Alan Diduck, Gary Katz, and John Myers; and last but not least David Martin. 
The case of Robert Latimer has provoked heated debate amongst people of good will who have conflicting views on his fitting punishment. I do not expect that a reader whose position is different from mine will be turned around by what I have to say, but at least I hope that this paper will cause her to ponder my case against his mandatory sentence.

\section{Prologue}

David Martin is the provincial co-ordinator of the Manitoba League of Persons With Disabilities. David is 37-years-old and has held that position for sixteen years. The League is an advocate for the disabled and also issues reports on social policy concerns affecting the disabled in such areas as transportation, home care, and housing. David was born with a genetic condition called spinal muscular atrophy. Although at one time he had some use of his limbs, his condition has so deteriorated over time that he is now quadriplegic, only able to wiggle a few fingers. A portable ventilator enables him to breathe through a tube surgically implanted in his throat, although he can breathe unaided for a few hours. According to David, his condition is comparable to a prolonged state of amyotrophic lateral sclerosis (Lou Gehrig's disease). Yet, in spite of the hand dealt him by Mother Nature, he has an indomitable spirit, an engaging personality, and a keen and penetrating mind. He holds a bachelor degree from the University of Winnipeg with a major in political science, and his aptitude for journalism is reflected in numerous op-ed articles that he has written for the Winnipeg Free Press on disability issues.

David and I frequently cross paths because of our mutual interest in medico-legal issues. Last November I invited him to attend a seminar class of third-year law students to present a disability perspective on the issues of assisted suicide and voluntary euthanasia: whether a physician should legally be allowed to comply with the request of a suffering patient for drugs to enable her to kill herself or for a lethal injection when she is physically unable to cause her own death. As David told the class, he and other disabled Canadians do not regard legalization of such means of death as a victory for patient autonomy - but rather as a new form of discrimination in the guise of promoting the rights of the disabled. When I mentioned the case of Sue Rodriguez, he responded that he and others in the disabled community were alarmed by her claimed right to physician-assisted suicide. ' He explained that although they are committed to the principle of patient autonomy - for how could a disabled person feel otherwise? - their concern was that assisted suicide could evolve from a right into a duty. The fear was that somewhere down the road people with disabilities might come to feel compelled to commit suicide or submit to euthanasia in order to reduce the strain on health care budgets and social programs.

In the case of Rodriguez v. Attorney General of Canada, [1993] 3 S.C.R. 519, the Supreme Court denied the petitioner's Canadian Charter of Rights and Freedom challenge (Part I of the Constitution Act, 1982, being Schedule B to the Canada Act (U.K.), 1982, c. 11 [hercinafter Charter] to the ban against assisted suicide in s. 241(b) of the Criminal Code (R.S.C. 1985, c. C46) [hercinafter Criminal Code]. 
His lucid and forceful comments provoked a lively class discussion, and a number of students who support legalization acknowledged that David had imparted a perspective that they had not thought about. As one student remarked:

I thought it (legalization) was just a straightforward issue but as you said it isn't that simple. Given what we hear and read in the media about our health care system, $I$ can see that it isn't that farfetched that patients could be subjected to the kinds of pressures to save the system money that you've talked about. $^{2}$

Being the professor enables one to have the last word and as the class wound down, I exercised that prerogative by offering the following comments. Proponents of the legalization of voluntary euthanasia and assisted suicide package their proposal as the medical measure of last resort - as an option for consenting patients when there are no alternative measures that can relieve intolerable pain and suffering. Consider, then, two societies - Freedonia and Ptomania - in which that option is lawfully available. In Freedonia there is a clear commitment to relieving the distress of severe disability. There are economic and human resources that guarantee such measures as state-of-theart pain control, widespread availability of palliative care, independent home living arrangements for patients who desire freedom from institutional care, and respite relief for families providing home care for stricken relatives. In that society, the options of voluntary euthanasia and assisted suicide can fulfil their role as the medical measures of last resort.

However, in Ptomania there is no comparable commitment, not necessarily because of a lack of good will but rather because the resources to meet that pledge are simply not available. In that society - where, for example, palliative care is available to less than five percent of the dying (which, by the way, is the case in Canada) - the last resort promise is a mockery. ${ }^{3}$ Because of the inadequacies of the health care and social service systems, the hemlock option could still be packaged as the medical measure of last resort simply because there are no viable alternatives to relieve the anguish of intolerable pain and suffering. In fact, voluntary euthanasia and assisted suicide could come to be seen as a cost-effective measure, far cheaper than the resources allotted by Freedonia for the care of the afflicted. I then said that, as Canada headed into the next millennium with an aging population that would put even more strain upon its commitment to the welfare of the physically and mentally afflicted, it would be fanciful to suggest to David that his concerns were not well founded.

Time constraints precluded a class discussion of other issues affecting the disabled, which David and I have talked about on other occasions. Around the time of his visit to the law faculty, he had at my request critiqued a draft of a paper I had written about

2 I took notes of the students' comments in a form of shorthand I learned years ago as a newspaper reporter, and the student is quoted verbatim.

Canada, Of Life and Death: Report of the Special Senate Committee on Euthanasia and Assisted Suicide (Ottawa: Minister of Supply and Services Canada, 1995) at A-90. 
two Manitoba cases, Child and Family Services of Central Manitoba v. R.L. and S.L.H. ${ }^{4}$ and Sawatsky v. Riverview Health Centre. ${ }^{5}$ The $L$. and $H$. case was a decision by the Court of Appeal, which ruled that a physician had the unilateral right to make nontreatment decisions - the case involved a DNR (do not resuscitate) order - over the objection of patient or surrogate. The case dealt with a claimed positive right that a physician must provide treatment that is requested by patient or surrogate. In effect, the Court denied such a right by ruling that a patient (or family member) cannot enforce a demand for treatment that the physician regards as futile.

The Sawatsky case was brought to the Court of Queen's Bench by the wife of a 79year-old incompetent patient. When his physician refused to withdraw a DNR order from his medical chart, she asked the court to enforce her demand. Although the judge was bound by the ruling in the $L$. and $H$. case, she did order two independent medical evaluations of the patient, expressing the hope that they would help resolve the conflict. In the result, although the evaluators found the DNR order appropriate, the case was closed when Riverview agreed to discharge the patient. The case attracted nationwide media coverage, and Mrs. Sawatsky was quoted as saying about her husband: "They have written him off. The older you get, the more vulnerable you become, the more expendable you get." Her conflict with Riverview prompted comments from the disabled community that unilateral DNR orders were an infringement of patients' entitlement to health care, which is why the Manitoba League of Persons With Disabilities sought and was granted intervenor status in the case.

Issues of medical futility are beyond the scope of this paper, but suffice it to say that the opinion has been voiced in disability circles that patients may be undertreated on the basis of social value judgments as to the worth of their lives that are packaged as purely medical judgments. It is one thing for a physician to refuse a treatment demand that has no hope of benefitting the patient. It is another thing when the refusal is grounded in a physician's quality-of-life assessment that may not be shared by a competent patient (or as in the Sawatsky case by the next-of-kin of an incompetent patient). As Laurie Beachell, national co-ordinator of the Council of Canadians With Disabilities, puts it:

The greatest fear of some disabled people is not that if they go into hospital they will be kept alive against their wishes - but that someone will put a "Do not resuscitate" sign over their bed and they won't come out again.'

David Martin and other disability rights advocates have also expressed reservations about the entrenchment in Canadian law of the negative right to refuse treatment. Although they welcome the right to say no to unwanted treatment, they recognize that

(1997), 123 Man. R. (2d) 35 [hereinafter $L$. and $H$.]. The paper - "A Do Not Resuscitate Order For an Infant Against Parental Wishes: A Comment on the Case of Child and Family Services of Central Manitoba v. R.L. and S.L.H." - will appear in a forthcoming issue of the Health Law Journal, a publication of the University of Alberta Health Law Institute.

[1998] M.J. No. 506 (QL). The case is unreported. Riverview is an extended care facility.

N. Moharib, "They're trying to play God" Winnipeg Sun (10 November 1998) 3.

M. Nichols, "Sympathy and Anger" Maclean's 110:46 (17 November 1997) 16. 
a patient's refusal of life-prolonging treatment should not simply be heralded as an affirmation of a so-called "right to die." In 1992, the Quebec Superior Court decided the landmark case of Nancy B. v. L'Hotel Dieu de Quebec, ${ }^{8}$ in which for the first time a Canadian court ruled that a mentally competent patient had the right to enforce her demand for the removal of artificial life-support (the 24-year-old patient had been rendered totally and permanently paralysed by a neurological disorder). Although lauded by the media and academics as a victory for patients' rights, the decision provoked a less sanguine response from the disabled community. It was typified by a comment by a spokesperson for the Canadian Paraplegic Association: "What concerns me is the ease with which people have accepted her life as worthless, to be so ready to help her die."

Furthermore, as David and others have rightfully pointed out, the patient's right to say no to treatment becomes a mockery - an invitation to die - unless coupled with a commitment by society to provide medical and community resources sufficient to enable the patient to make the best of her lot in life. The point is illustrated by an American case that my students read along with Nancy B. - a 1989 ruling by the Georgia Supreme Court which eloquently affirmed the right of a mentally competent quadriplegic patient to compel the removal of his respirator. State v. McAfee involved a 30-year-old patient who had been paralysed for four years since a motorcycle accident. He had sought to die because life held no attraction, but then something happened. The publicity ensuing from the decision served to mobilize public and private resources for the handicapped; when a variety of social services (including a voice-activated computer) were made available to the patient, he chose to forgo his "right to die."

Once again, we have the two societies metaphor that I have used in the context of voluntary euthanasia and assisted suicide. If opportunities are made available to the patient to enhance her quality of life, then the decision to refuse life-prolonging treatment is truly the exercise of free choice. But if not, then the lack of commitment becomes in effect an invitation to the patient to exercise her "right" to refuse lifeprolonging treatment.

As David has said, all these issues - voluntary euthanasia, assisted suicide, medical futility and the demand for treatment, and the right to refuse treatment - are "of a piece." They all address the plight of the disabled, and in a society with a beleaguered health care and social services system, each in its own way can be perceived as a threat to the well-being of the disabled.

These are concerns that I share with David and have expressed in a variety of forums: seminars with law students, presentations to health care professionals, interviews on radio and television, and law journal articles. Although we have found ourselves in agreement on public policy matters affecting the disabled, there is one

R. Turner, "Nancy B. Mourned, Celebrated" Winnipeg Free Press (14 February 1992) A2.

10 385 S.E.2d 651 (Ga. Sup. Ct. 1989).

(1992), 69 C.C.C. (3d) 450 [hereinafter Nancy D.]. 
issue where we have parted company - the appropriate punishment for Robert Latimer, the Saskatchewan farmer who asphyxiated his severely disabled 12-year-old daughter by venting exhaust fumes from his pickup truck's tail pipe into the cab where he had placed her." At Latimer's first trial in 1994, he was convicted of seconddegree murder and received the mandatory minimum sentence for that offence as stipulated by s. 745(c) of the Criminal Code - life imprisonment without eligibility for parole for ten years. A new trial was ordered by the Supreme Court of Canada because of prosecutorial misconduct, but once again Latimer was convicted of seconddegree murder.

This time, however, the trial judge refused to follow the Criminal Code provision on sentencing for second-degree murder. In a stunning decision, Noble J. ruled that, given the facts of the case, the mandatory life sentence breached s. 12 of the Charter (the prohibition against cruel and unusual punishment), and therefore a constitutional exemption from that punishment was in order. ${ }^{12} \mathrm{He}$ accordingly handed Latimer a two year sentence, the first year in custody and the second confined to his farm. That decision was reversed by the Saskatchewan Court of Appeal, which imposed the mandatory minimum sentence. The case is back on its way to the Supreme Court, and if the appellate court judgment is affirmed, then Latimer will spend the next decade in prison (unless at some point a pardon is forthcoming from the Minister of Justice).

My hope is that the sentence handed down by Noble J. will be reinstated, while David Martin is fervently of the opposite view. In an op-ed article written after the first trial, he deplored expressions of support for Latimer, stating: "Unlike many people without disabilities, we feel horror about what Latimer did to his daughter Tracy. We are hurt that so many people cannot see the horror we see.... A grave and irrational crime was committed against a little girl (and) as sure as we are that our lives have hope, we are surely not convinced that Tracy's life was hopeless." ${ }^{.13}$ Although not without sympathy for Latimer, he still had no qualms in concluding that "Latimer must serve his sentence like others who are convicted of second-degree murder." ${ }^{\prime 4} \mathrm{He}$ has held to that position and consequently disapproves of Noble J.'s sentencing decision.

Gravely affected at birth by cerebral palsy, Tracy Latimer was a totally body-involved spastic quadriplegic, whose constant muscle spasms and seizures had wrenched her body into a twisted frozen position. She weighed 38 pounds, was incontinent, had impaired vision, and could not sit up, talk, or feed herself. Although severely mentally handicapped, she seemed to enjoy being with her parents and other children, riding on the school bus, and listening to music. See $R$. v. Latimer, [1995] 8 W.W.R. 609 at 614-15, 656-57 [hereinafter Latimer]. Also see M. O'Hanlon, "Tracy Was in Extreme Pain, Latimer Murder Trial Hears" Winnipeg Free Press (31 October 1997) B2. $R$ v. Latimer, [1997] S.J. No. 849, online: QL (S.J.). It is largely forgotten that Noble Q.B.J. was not the first judge to rule that a constitutional exemption from the mandatory life sentence was warranted in the Latimer case. When a three-judge panel of the Saskatchewan Court of Appeal upheld Latimer's first conviction and ten year minimum sentence, Chief Justice Bayda filed a lengthy opinion upholding the conviction but striking down the sentence as cruel and unusual punishment under s. 12 of the Charter. See Latimer, supra note 11 at 651.

13 D. Martin, "Tracy's Right to Life Was Taken From Her" Winnipeg Free Press (3 August 1995) A7. 
The sentiments expressed by David about Robert Latimer - his crime and the fitting punishment - have been echoed time and time again by disabled Canadians during the five years that the case has been winding its way through the courts. The killing of Tracy Latimer has struck a raw nerve in the disabled community - by which I mean not only the disabled themselves but also their caregivers (often their parents) - and the intensity and passion of the sorrow at her death has been matched by the intensity and passion of the anger directed at her father. I do not excuse what Latimer did, but then I do not believe that the punishment that they demand fits the crime, as I hope to show later in this paper. David and I have seen eye to eye on so many disability issues that I find it troubling that a case has arisen that finds us at odds. Over the years I have exchanged views not only with David but also with many others in the disabled community about the Latimer case, and I acknowledge the pain and anguish that they bring to the crime and its punishment. ${ }^{15}$

\section{Principles of Sentencing}

When the Latimer case is heard by Canada's court of last resort, the disability groups granted intervenor status will plead for the affirmation of his life sentence. However, before anyone can be deprived of liberty by the criminal justice system, there must be a principle (or principles) of punishment supporting the sentence. ${ }^{16}$ There are three principles at issue in the Latimer case - general deterrence, retribution, and denunciation - and each has been argued as sufficient reason to reject the sentencing decision of Noble J. ${ }^{17}$ (Mandatory minimum sentencing for murder adds nothing new to the time-honoured principles of punishment. As the trade-off for the abolition of capital punishment for murder in 1976, it came wrapped in the mantle of deterrence. The police lobby and its Parliamentary allies were prepared to support abolition only if the noose were replaced by mandatory minimum sentences. Their rationale was that, if the death penalty were no longer available as a deterrent to murder, then the breach must be filled by mandatory lengthy imprisonment. ${ }^{18}$ )

Let us then take each of the three principles in turn and see whether it can make the case for Latimer's life sentence.

I readily acknowledge that some of the most passionate proponents of the mandatory sentence for Latimer are not members of the disabled community. But they are not my concern in this paper. Section 726.2 of the Criminal Code stipulates that "(w)hen imposing a sentence, the court shall state ... the reasons for it...."

According to s. 718 of the Criminal Code, the principles of sentencing are: (a) to denounce unlawful conduct; (b) to deter the offender and other persons from committing offences; (c) to separate offenders from society, where necessary; (d) to assist in rehabilitating offenders; (c) to provide reparations for harm done to victims or to the community; and (f) to promote a sense of responsibility in offenders, and acknowledgement of the harm done to victims and the community. Section 718.1 then states: "Fundamental Principle - "A sentence must be proportionate to the gravity of the offence and the degree of responsibility of the offender." I think it self-evident that only (a) denunciation, (b) general but not specific deterrence, and the combination of ( $f$ ) and $s$. 718.1 (retribution) are addressed by the Latimer case.

House of Common Debates (6 May 1976) at 13253-54. 


\section{A. General Deterrence}

Firstly, there is general deterrence - the expectation that by punishing the offender, others will be deterred from following in her footsteps. General deterrence thus rests on the questionable premise of punishing a criminal to set an example for others. In other words, we are not saying to the offender that she necessarily deserves her sentence, but rather that it is imposed to discourage others from emulating her example. As Clayton Ruby explains in his text, Sentencing:

The theory is based on an economic model of crime which assumes that criminals weigh the likely gains against the likely consequences of the offence and commit offences only where the perceived gains outweigh the perceived consequences."

However, there is precious little evidence of the general deterrent effect of punishment, keeping in mind the adage that it is not the severity but rather the certainty and swiftness of punishment that is more likely to deter. From the little we know, general deterrence may work for generally law-abiding citizens who are thinking about committing acquisitive crimes such as theft or embezzlement. It is also likely that some motorists refrain from drinking because they are deterred by severe penalties for impaired driving (although all too many do not). But there is really no evidence that severe penalties - even death - are a deterrent to murder or that punishment however severe is in itself a deterrent to crimes of violence. ${ }^{20}$ That is because the offender who resorts to violence is typically not the calculating rational actor posited by the deterrence model.

It is nevertheless argued that the principle of general deterrence justifies at the very least a minimum ten year sentence for Robert Latimer. This was the thrust of the factum filed by a Winnipeg disability rights organization, which was granted intervenor status when Latimer's first conviction was reviewed by the Saskatchewan Court of Appeal. According to the factum, if Latimer's conviction and sentence did not stand, then

[e]very disabled person who was perceived to be living a miserable existence would be at risk. Such persons would be put to the ongoing obligation literally to "justify their existence." Such a principle, especially in the face of ever-declining resources for health care, would mean an ever-present prospect of doom for persons in continuing need of health care. ${ }^{21}$

This is the spectre of the floodgates or the slippery slope - that if the line is not held in the Latimer case, then parents and other caregivers who are weary of their burden will be encouraged to kill their disabled dependents under the cloak of compassion in the expectation that they too will escape the full rigour of the law.

19 C.C. Ruby, Sentencing, 5th ed. (Toronto: Butterworths, 1999) at 10.

211 V. Kappeler, M. Blumberg \& G. Potter, The Mythology of Crime and Criminal Justice, $2 \mathrm{~d}$ ed. (Prospect Heights, Illinois: Waveland Press, 1996) at 334-36. D.M. Paciocco, Getting Away With Murder: The Canadian Criminal Justice System (Toronto: Irwin Law, 1999) at 28-31. Latimer, supra note 11 (Intervener factum, People in Equal Participation, Inc. at 5-6). 
(Such, in effect, is the position of Margaret Somerville, professor of law and medical ethics at McGill University, who responded to the two year sentence of Noble J. by claiming that it put the lives of 4,000 Canadians - those with cerebral palsy of comparable severity to Tracy's - at risk. ${ }^{22}$ )

I readily acknowledge that the factum expresses a legitimate concern for the rights of the disabled "in the face of ever-declining resources for health care." ${ }^{23}$ However, I submit that where the slippery slope is truly found is in the cutbacks in health care and social services for people with disabilities and their families - that if anything it is not the Latimer case but rather inadequate public funding and community resources that imperil the lives of the disabled.

Furthermore, it is fanciful to believe that a life sentence will deter whereas all that has happened to Latimer in the last five years will not. In that five years, Latimer has undergone two trials and three appellate proceedings with one still to go. He has seldom been out of the public eye and has been damned and vilified both from within and without the disabled community. And his wife has spoken of the anxiety and heartbreak of living under the pall of the life sentence that could mark the last chapter of the case. I am unpersuaded that a caregiver tempted to follow Latimer's example would not be deterred by the five year (and still running) ordeal experienced by the Latimers but would be deterred by the ten year minimum sentence.

Even if Noble J.'s two year sentence were reinstated, our murderously inclined caregiver surely would know that there was no guarantee that a second Latimer case would produce a similar result. She likely would realize that another killing of a disabled dependent would spark a wave of protest and anger that might well exceed that generated by the killing of Tracy Latimer, and further that the circumstances of the killing would be subjected to intense scrutiny by the Crown, the media, and the disabled community. In other words, if there were the kind of calculation that is posited by the theory of deterrence, then she would know - whatever Latimer's fate - the great risk in going ahead.

Of course, there is no predicting how an emotionally distraught and irrational caregiver with murder in her heart might react to Latimer's ultimate sentence, whether it be two years or a ten year minimum. If such a person exists, she is in any event not likely to engage in the balancing act that grounds the deterrence principle.

I am not saying that someone could not be driven by desperation to do what Latimer did, but, if that happens, it will happen regardless of his ultimate fate. To think otherwise is to ignore the historical experience that penal sanctions exert little if any deterrent impact upon murder and other crimes against the person. In sum, the principle of deterrence cannot make the case for Latimer's life sentence. 


\section{B. Denunciation}

Secondly, there is the sentencing principle of denunciation - that there are crimes which are so outrageous as to warrant severe punishment in order to "reflect society's view of the wrongness of the conduct." 24 In the Latimer context, it finds expression in such comments as that of Pat Danforth of the Council of Canadians With Disabilities, who interpreted Noble J.'s sentence as signifying that " $[w]$ e're telling every senior citizen, every quadriplegic, anyone injured in a car accident that their life is of diminished value."25

In Canada, the purely denunciatory aspect of sentencing is typically found in cases involving crimes against children. When children have been sexually assaulted or otherwise brutalized, it is reasonable to assume a public consensus grounded in indignation and revulsion. But that kind of consensus has not emerged in the Latimer case; and, if anything, the nationwide outpouring of sympathy for Robert Latimer would appear to belie the blanket community disapproval that arguably undergirds a denunciatory sentence. According to a recent Angus Reid poll, seventy-three percent of respondents supported the proposition that Latimer "acted out of compassion and should receive a more lenient sentence." Only twenty-three percent agreed that he "murdered an innocent child and should pay the full penalty of second-degree murder."26

Public reaction aside, there is the contention that a denunciatory sentence is fitting in the Latimer case because the law must send the message that the killing of a disabled child is no less a crime than the killing of a non-disabled child. From that standpoint, the widespread sentiment in favour of leniency is cancelled out by the necessity to impress upon the public consciousness that - whether disabled or not - every human life is of inherent and equal worth. Ms. Danforth's is but one of many voices in the disabled community to contend that, if Latimer is treated differently from other murderers, it would signify that the lives of the disabled have diminished value. (Aside from its denunciatory aspect, this argument also smacks of general deterrence - that Latimer's sentence must be designed to discourage other caregivers from killing their handicapped dependents.)

Although one cannot quarrel with the message, a diminished respect for the disabled does not explain the killing of Tracy Latimer. As Noble J. noted in his ruling, "the evidence does not in any way suggest he killed his daughter because she was so severely disabled."27 It is true that if she had not been gravely afflicted with cerebral palsy, Latimer would not have killed her. Still, what explains the killing was not her disability as such. In an op-ed piece in the National Post in October 1998, Judith Snow, the quadriplegic chairperson of the Ontario Advocacy Coalition, wrote that, if Tracy

R. v. Spence (1992), 78 C.C.C. (3d) 451 at 454 (Alta. C.A.).

D. Roberts, "Latimer Sentence Termed 'Travesty of Justice"" The Globe and Mail (2 December 1997) A8.

J. Sallot, "Latimer Sentence Too Harsh, Poll Told" The Globe and Mail (11 January 1999) A5.

Supra note 12 at 19. 
were then alive, she would soon be celebrating her sixteenth birthday. And how would it be marked, she ponders: "How about a henna tattoo, and an accessible taxi to the school dance accompanied by some school chums to make sure all goes well? Afterwards, some pizza and music in the rec room to round out a perfect birthday." 28 Alas, this would never have been even if Tracy had lived as her horizons were more limited. Her father did not end her life because she could not derive pleasure from a school dance or pizza with school chums. There were little pleasures that marked her life and her parents treasured them, but there was also the pain that blighted her life and theirs as well.

According to Clayton Ruby: "[A]though denunciation is now an approved, codified principle of sentencing, the appropriate application of that principle can be assessed only on the facts of a particular case." 29 Thus, if Latimer had killed his daughter out of contempt for her life as a disabled person, then the law would be right to hand down a denunciatory sentence. But there is no evidence that he ever thought the less of his daughter because of her handicaps. (If he had disvalued her life because of her disability, he surely would not have given her tender and loving care for so many years.) According to s. 718.2 of the Criminal Code, a court in imposing sentence should consider as an aggravating circumstance that "the offence was motivated by bias, prejudice, or hatred based on...mental or physical disability...." Latimer's motive was different; he acted not out of "bias, prejudice, or hatred" but out of compassion, however misguided. That is not enough to excuse his act, but it is enough to preclude the imposition of a denunciatory sentence. ${ }^{30}$

\section{RETribution}

Retribution - or just deserts - is the principle that the offender should receive the penalty that he deserves. Its rationale is that it is a matter of fundamental fairness to require the offender to pay back society for the harm committed. In the words of penal theorist Andrew von Hirsch:

The offender may justly be subjected to certain deprivations because he deserves it; and he deserves it because he has engaged in wrongful conduct - conduct that does or threatens injury and that is prohibited by law. The penalty is thus not just a means of crime prevention (deterrence) but a merited response to the actor's deed, "rectifying the balance" in the Kantian sense and expressing moral reprobation of the actor for the wrong."

At first blush, retribution sounds suspiciously like denunciation. But whereas the focus of denunciation is upon the community's condemnation of the offence in question, the spotlight of retribution rests upon the offender and the harm caused by his

J. Snow, "For Whom The Bell Tolls: The Public Wonders If I Should Be Allowed To Live" The National Post (28 October, 1998) A18.

29. Supra note 19 at 6.

3) This comment would apply with equal force to a retributive sentence.

31 A. Von Hirsch, Doing Justice: The Choice of Punishments (New York: Hill and Wang, 1978) at 51. 
crime. I grant that there is no clear dividing line between the two, as it is reasonable to assume that the sense of public outrage that a judge brings to a sentencing decision is in all likelihood linked to the degree of blameworthiness that he attaches to the offence in question. Yet, it still pays to keep the concepts separate and apart because it is only retribution that asks not what society demands but what the offender deserves. In that sense, retribution is arguably the most legitimate principle of punishment because it puts the spotlight directly where it belongs: upon the offender and what he deserves for what he has done. That is, I suggest, the sense of Parliament as well, since s. 718.1 of the Criminal Code declares: "Fundamental principle - A sentence must be proportionate to the gravity of the offence and the degree of responsibility of the offender." (In that regard, those who oppose leniency for Latimer contend that a mandatory minimum ten year sentence is his just measure of pain.)

Of course, there is no exact scale to determine the penalty necessary to redress the imbalance caused by an offender (the only exact measurement - in the sense of an eye for an eye - is the death penalty for murder and, then, only when there is but one victim per offender). Nonetheless, in our imperfect world judges are accustomed to relying upon their experience and their knowledge of sentences handed down by their peers to determine the punishment deserved in the particular case. In that sense, it is a scale of relativity that counts - striving for a pattern of sentencing that correlates punishment with blameworthiness on a case by case basis.

Criminal Code offences typically allow for a wide range in sentencing. There are, for example, a number of offences - including robbery, kidnapping, arson, extortion, aggravated sexual assault, criminal negligence causing death, and manslaughter - that provide a maximum sentence of life imprisonment but no mandatory minimum sentence. $^{32}$ There are also a wide number of offences that carry maximum sentences of fourteen, ten, and five years but, again, no mandatory minimum. ${ }^{33}$ Furthermore, although an offender is generally eligible for parole after serving one-third of the sentence, s. 743.6(1) of the Criminal Code allows the judge to order for certain stipulated offences that "the portion of the sentence that must be served before the offender may be released on full parole is one half of the sentence or ten years, whichever is less." Even a life sentence means parole eligibility after seven years unless it is increased to ten years under this proviso.

Thus, the dominant philosophy of sentencing in the Criminal Code is to provide judicial discretion to tailor the punishment to the crime and the criminal. What the ceiling (maximum sentence) sets out is the appropriate sentence for the worst kind of offender committing the act in the worst possible circumstances, whereas the most lenient sentence - an absolute discharge - would be appropriate when the circumstances of the offender and the offence fall at the other end of the scale. And the extortion, s. 346(1.1)(b); aggravated sexual assault, s. 273(2)(b); criminal negligence causing death, s. 220(b); and manslaughter, s. 236(a). 
broad sentencing range between the extremes simply reflects the reality that there is virtually an infinite variety of aggravating and mitigating factors that can distinguish one crime from another crime of the same legal kind.

A recent case with a relatively severe sentence for criminal negligence causing death was that of a New Brunswick couple, Steven and Lorelie Turner. The horrific nature of their crime attracted nationwide media attention; the victim was their three-year-old son who was subjected to the most unspeakable physical and emotional abuse. His last days were spent bound to a bed in a darkened room, gagged with a sock to stifle his cries. The pathologist found his stomach lined with black scars of numerous haemorrhages that were likely caused by repeated bouts of crying. There was evidence that he died not only from physical abuse but also from emotional dwarfism - that the abuse caused him to wither away and die.

In affirming their sixteen year sentence, the Court of Appeal ruled that it was a fit and reasonable punishment for a horrendous crime. ${ }^{34}$ Still, the Turners will be eligible for parole after one-third of their sentence: five years and four months. And even if the book had been thrown at them, so to speak, s. 743.6 would have precluded their serving more time before parole eligibility than that facing Latimer.

There are, alas, all too many cases short of murder - sexual assaults whose ravaged and forever traumatized victims include offenders' children and stepchildren; home invasions where the occupants are terrorized, beaten, and robbed; and parents as callous as the Turners whose abject neglect causes irreparable harm, if not death, to their children - that cry out for the heavy hand of the law. They are the kind of cases that produce lengthy sentences grounded in the principles of deterrence, denunciation, retribution, and incapacitation. ${ }^{35}$

Consider, for example, two Alberta cases, R. v. S.G.O.R., ${ }^{36}$ and $R$. v. S.(W.B.). ${ }^{37}$ In the former, the accused was convicted of the rape of his daughter (he raped her at least twenty times during an eight year period beginning when she was four-years-old) and of sexual assaults against his 13-year-old adopted daughter and seven-year-old niece. His sentence on appeal: three years for the rapes and three months (concurrent) for each of the sexual assaults. In the latter case, the accused was convicted of repeated acts of anal intercourse over a two year period with his stepdaughter (from the time she was six-years-old) and stepson (from the time he was eight-years-old). His sentence on appeal: seven years. These were decisions by the Alberta Court of Appeal, and in each case the Court increased the sentence of the trial judge.

$34 \quad$ R. v. Turner (1997), 185 N.B.R.(2d) 190 at 225.

is Incapacitation, which is not an issuc in the Latimer case, is the principle that an offender must be detained for the safety of the community.

36 (1991), 113 A.R. 36. The crime of rape has since been abolished and replaced with various sexual assault offences under ss. 271-73 of the Criminal Code.

37 (1992), 73 C.C.C.(3d) 530. 
I imagine that there is not a Canadian judge who has heard criminal cases who could not produce her own litany of offenders of comparable depravity but whose crimes have stopped short of murder. The point is that there is no offence other than murder - no matter how heinous its circumstances or how dreadful the offender - that can produce a sentence with longer time before parole eligibility than that dictated by Latimer's murder conviction.

Yet if the emphasis is upon just deserts, then blameworthiness must come to focus not only upon the offence but also upon the offender. That is because one cannot divorce the act from its doer in the assessment of "the moral reprobation of the actor for the wrong." ${ }^{38}$ It thus follows that a judge seeking a retributive sentence must consider not only the harm caused to the victim but also the offender and his background and circumstances. As underscored by Madam Justice McLachlin in a 1997 Supreme Court case, $R$. v. McDonnell: "A just sentence is one which reflects the seriousness of the crime and fits the individual circumstances of the offender." ${ }^{39}$

What, then, of Latimer and his crime? When convicted at his first trial, he was immediately sentenced to the mandatory minimum punishment for second-degree murder. The Criminal Code directs trial judges to consider both aggravating and mitigating factors in sentencing, and presumably the trial judge found that the circumstances of the crime clearly established sufficient mitigation to warrant the minimum sentence. When convicted the second time, there was an extraordinary response by the jury. After the verdict, Noble J. asked the jury to recommend whether Latimer should receive the mandatory minimum sentence, or whether he should serve more than ten years before eligibility for parole. ${ }^{40} \mathrm{~A}$ number of jurors appeared distraught upon learning that there was a mandatory ten year minimum, and when the jury returned from deliberations it defiantly recommended that Latimer be eligible for parole after one year's confinement. ${ }^{41}$ When Latimer was convicted the first time, he turned to the jury and bitterly said, "I don't think you people are being human." 42 This jury was being human, and Noble J. responded in kind. In allowing for a constitutional exemption in this case, he stressed that the evidence established that Latimer was

a caring and responsible person and that his relationship with Tracy was that of a loving and protective parent...(and that he) was motivated solely by his love and compassion for Tracy and the need - at least in his mind - that she should not suffer any more pain..... ${ }^{43}$

Supra note 31 .

[1997] 1 S.C.R. 948 at 983.

Section 745.2 of the Criminal Code provides that when an accused is convicted of second degree murder, the judge shall ask the jury for any recommendation as to the number of years (between ten and twenty-five) that should be served before parole eligibility. The judge is directed to inform the jury that it is not required to make a recommendation but that, if it does, it will be considered in the sentencing decision.

Supra note 12 at 14.

F. Harris, "A Child Dies" Chatelaine (April 1995) 13 at 108.

Supra note 12 at 18. 
It was uncontested that pain was a constant feature of Tracy's life, but it is also uncontestable that as the Crown prosecutor at the second trial told the jury, "[p]ain is a condition of life, not a reason for death." ${ }^{44}$ Still, it was his daughter's pain — pain past, present, and future - that drove him to the conviction that the only way to end her pain was to end her life. The strongest pain-killer that Tracy could take was regular Tylenol because the anticonvulsant medication that controlled her seizures precluded the resort to more potent pain-killers (such as narcotics). The combination could have drastic consequences. Tracy had a poor gag reflex and limited respiratory functioning, and drugs to combat pain ran the risk of causing her to stop breathing or choke to death. ${ }^{45}$ Still, Tracy was not in pain all the time but she was in pain much of the time; she had her good days and she had her bad days. And the bad days - year after year - drove Latimer (and his wife) to distraction.

My wife, a longtime pediatric and neonatal nurse, has quoted to me an old refrain: "A child's hurt is a parent's hurt. A child's pain is a parent's pain." It was Tracy's hurt and Tracy's pain that gnawed at the Latimers for years, and then her father reached the breaking point when hip surgery was scheduled by Dr. Anne Dzus, a pediatric orthopaedic surgeon. Dr. Dzus proposed to remove the ball part of the ball-and-socket hip joint and the top of her femur, leaving her leg attached to her body only by muscle and tissue. ${ }^{46}$ (But since Tracy could not walk in any event, there would be no point in replacing the ball.) However, for both Robert Latimer and his wife, Laura, the surgery was seen as the mutilation of their daughter's ravaged body. It meant that their daughter was going to be "cut up," and they were appalled at the prospect. ${ }^{47}$ Furthermore, Dr. Dzus had warned that there likely would be "incredible" postoperative pain that could only be controlled in the short term, and that additional surgeries were in the offing. ${ }^{48}$ As Latimer told the police eleven days after Tracy's death, "[m]y priority was to put her out of her pain. Each time you moved her, she was in pain. We just couldn't see another operation ... so I thought the best thing for her was that she be out of pain."

Latimer insists that he ended his daughter's life as an act of compassion. His critics see it differently. In a National Post article titled "No suffering in Robert Latimer," Christie Blatchford called it an act of "remarkable unsentimentality" and "unshakeable sureness." In her view, he "treated his little girl the way he might have any other sick animal, like a pig, because he applied the law of the farm to a human being...." 51 Referring to the plight of Saskatchewan pig farmers facing plummeting pork prices, she

S.D. Driedger, "Should Robert Latimer Go Free?" Maclean's (17 November 1997) 13 at 14. Testimony of Dr Anne K. Dzus, Tracy's pediatric orthopaedic surgeon, at the first trial. Transcript, The Court of Queen's Bench, Judicial Centre of Battleford, $R$. v. Latimer, Criminal Trial (Jury), Commencing Nov. 7, 1994, Cross-Examination, Vol. 1, page 183.

Ibid. at 173-74.

Infra note 62.

O'Hanlon, supra note 11.

M. O'Hanlon, "Mercy Is Not An Excuse, Latimer Jury Concludes" Winnipeg Free Press (6 November 1997) A2.

C. Blatchford, "No Suffering In Robert Latimer" National Post (28 November 1998) at B8. Ibid. 
wrote that one, unable to feed or sell his pigs, had killed them by gassing them in his pickup truck with a hose from his car. As she added, "just like Bob Latimer did with Tracy." 52 Blatchford is not the first to invoke the chilling metaphor of "the law of the farm" - or "barnyard ethics" - to describe the fate of Tracy Latimer. ${ }^{53}$ Here is the busy farmer on his daily rounds, barely breaking stride as his practiced eye scans an ailing pig. He shakes his head, mutters a sentence of death, and then unceremoniously tosses it into his mobile gas chamber. And then he repeats the same procedure with his daughter. Farm animal, farm daughter, it is all the same to him. A powerful indictment indeed, although I wonder what metaphor Blatchford would have used had Latimer happened to live and work in town.

Be that as it may, Latimer did not end his daughter's life because he was a farmer accustomed to summoning a veterinarian to put down a sick animal. Argue, if you will, that murder is murder and that he must pay the piper with at least ten years of his life. But at least have done with the spectre of the farmer who in the same frame of mind kills a sick animal with one hand and a sick daughter with the other. That is not the way it was. Latimer was not a farmer who was culling his flock. He was a grieving parent who could no longer abide his daughter's pain, and the nature of his calling is beside the point. It was pain - hers and his in response to it - that was the point, which is not to say that it excuses the killing. But it does explain it.

In the aftermath of Latimer's first trial, a lawyer with the Canadian Disability Rights Council compared the public response to his mandatory minimum sentence to that sparked by the notorious South Carolina case of Susan Smith, who had drowned her two young sons by pushing her car into a lake. Regretting the contrast between the widespread sympathy expressed for Latimer and the anger, outrage, and calls for the death penalty directed at Susan Smith, she concluded: "Who are we to say that because the Smith boys were able-bodied their lives were better than Tracy's? This is a classic imposition of a stereotype." ${ }^{\text {4 }}$

Implicit in her argument is the belief that the public would have expressed compassion for Smith if her children had been disabled. But surely that is wrong. Rather, what explains the disparate public reaction to the two cases is their respective motives - that Latimer killed his daughter because he could no longer abide her distress whereas Smith killed her children because they were an impediment to her relationship with her boyfriend, who had told her as much.

Again, one may say that murder is still murder and that the only question is whether Latimer intended to kill, not why he killed. In other words, what counts is mens rea, not motive. Murder was traditionally defined at Common Law as a killing with "malice aforethought," and malice did not require spite or ill will but simply the intent to kill.

$32 \quad$ Ibid.

s3 For example, the mother of a disabled child who attended the second trial commented, "lt's time these barnyard ethics are put to a stop." Supra note 44.

54 A. Mitchell, "Murder Sentence Stirs Angry Waves Across The Nation" The Globe and Mail (18 November 1994) A8. 
Even so, it is, I suggest, the dictionary entries for malice - rancour, grudge, malevolence, hatred, vindictiveness - that truly capture the public sense of the murdering mind. And at the end of the day, what remains is a severely handicapped child who was often in terrible pain and a father whose motive for murder distinguishes him from the vast run of murderers. ${ }^{\text {ss }}$

I say that because the evidence belies the portrayal of Latimer as an ogre who killed his daughter because she was an inconvenience (one of his critics even went so far as to suggest that he killed her because she was getting in the way at harvest time) ${ }^{56}$ On the contrary, the evidence is that he was devoted to his daughter, did not take the easy way out by institutionalizing her, and cared for her for the twelve years of her life with exemplary devotion and commitment. In short, he was a loving father who saw no end to his daughter's pain and decided that her death would be a merciful release.

I am not yet done with the application of retributive justice to Latimer, but enough has been said to question his current sentence on two grounds. First, his motive for murder was not grounded in a malicious heart as is almost invariably the case with those who intentionally kill. As law professor Bernard Dickens has pointed out, "[s]ome who represent disabled people may be quite comforted by (Latimer's) conviction. Other people will think it wrong that the law does not draw a distinction between the intention of a Clifford Olson and the misguided compassion on the part of Robert Latimer." 57 So, too, in Getting Away With Murder: The Canadian Criminal Justice System, David M. Paciocco comments with reference to the Latimer case:

Not all killers are alike, and not all killings are alike. Making them all share the same minimum penalty is preposterous: it is too rigid to be just. ${ }^{3 \mathrm{~B}}$

Second, a case can be made that his sentence is out of line when compared to the fate of offenders who have left their victims alive but devastated and scarred for life by emotional and physical abuse that would do the Marquis de Sade proud. That is because the Criminal Code does not permit an offender who commits a crime short of murder to serve more time before parole eligibility than Latimer currently faces - no matter how heinous the crime or how despicable its perpetrator. Disparity in sentencing is a frequent topic at judges' seminars, but as every judge knows uniformity in sentencing is an impossible dream. The reason is simple enough: we are dealing with the complexities of human behaviour and the mind sets from which it springs. So judges do the best that they can, and appellate courts tinker with sentences in an effort to iron out glaring disparities. But it can never be fine tinkering because the subject matter - measuring harm and ascribing responsibility - is not reducible to the

ss The point was grasped by one of the jurors at the second trial, who commended Noble J. for his sentencing decision. As she said: "I think the punishment now fits the crime. It wasn't a murder he did with malice, it was done with compassion." Supra note 26.

s. D. Sobsey, "Compassionate Homicide versus Equal Protection: A Disability-Rights Perspective" (December 1995) 7 The Bioethics Bulletin 5.

57 Supra note 44. Clifford Olson is Canada's most notorious serial killer and is serving a life sentence for torturing and murdering nine children.

58 Supra note 20 at 56. 
formula of the engineer or the accountant. It is fair enough to say that as a general rule, murder is the worst crime committed by the worst offender. That is the raison-d'etre for the law that has given Robert Latimer a life sentence, but I suggest that every judge who hears criminal cases knows that murder is not always the most shocking crime. (I shall reserve my comments on mandatory minimum sentencing until later.)

I have heard it said that compassionate homicide is a myth; that the so-called mercykiller acts not out of compassion but rather to rid himself of an inconvenience. But the fact is that such cases do occur, however infrequently, and the unique feature of the Latimer case is not his motive for murder but that he was convicted of that offence. I am aware of seven other Canadian mercy-killing cases in which the various accused were charged with murder, but not one produced a prison sentence. Two cases ended in jury acquittals, four in guilty pleas to lesser offences (two resulted in suspended sentences, the others in probation), and one to a discharge at the preliminary hearing. ${ }^{59}$ These results were not surprising because what distinguishes a mercy-killing case from all other murders is that the accused does not bear ill will toward the deceased. In that sense, one could say that the relationship between the parties is not adversarial. The crime is not an act of hostility; it is not explained by a base motive such as rage, jealousy, revenge, or greed. For that reason, it is no betrayal of Tracy Latimer to call for a compassionate sentence for the father who could not abide her pain. Theirs are not competing claims, so to be for one does not mean that one must be against the other. For Tracy was no adversary; she was the daughter that Latimer had diligently cared for and loved, but there came a time when the only way he knew to express that love was by ending her life. The law says that that is murder and fair enough. But still, the track record of our legal system - of prosecutors who agree to guilty pleas, of

The four guilty plea cases are discussed by C.J.S. Bayda, supra note 12 at 662-69. See also B. Sneiderman, J.C. Irvine \& P.H. Osborne, Canadian Medical Law: An Introduction for Physicians, Nurses and Other Healih Care Professionals, 2d ed. (Scarborough: Carswell, 1995) at 541-42, 546-47. One of the acquittals is discussed in Sneiderman et al. at 538-39; the other at B. Sneiderman, Latimer, Davis, and Doerksen: Mercy Killing and Assisted Suicide on the Op. Ed. Page (1998) 25 Man. L.J. 449 at 458-61. The case discharged at the preliminary hearing is that of Dr. Nancy Morrison. As Paciocco argues, notwithstanding that decision there clearly was enough evidence to go to the jury. See Paciocco, supra note 20 at 57-59. Furthermore, even if the Crown could not prove that she caused the patient's death, there was incontrovertible evidence that she was guilty of attempted murder as she did inject the patient with potassium chloride just before he died. (Administering that drug to a patient whose death is imminent can be for only one reason: to stop his heart.)

There are two additional cases that merit comment. In 1990, the Quebec Justice Ministry declined to charge a Montreal doctor who administered a lethal dose of potassium chloride to a dying AIDS patient. That decision was likely prompted by a recommendation by the Quebec College of Physicians that the doctor not be prosecuted. In 1995, the son of a terminally ill cancer patient was charged with attempted murder for feeding her large doses of painkillers to end her life. The attempt failed, and she died of the disease three days later. He pled guilty to the Criminal Code offence of "administering a noxious thing" (s. 245) and was placed on probation. In handing down the sentence, the judge said: "Given the fact that this was an act of love, it would be contrary to the whole philosophy of criminal law to incarcerate you." Similar remarks have been made by judges in the other cases. Sec Sneiderman et al., ibid. at 542-43, 547. 
judges who accept them and hand down compassionate sentences, and of juries who acquit - reflects the felt intuition that mercy-killings are different. ${ }^{60}$

\section{COMmentary}

The Latimer case is layered with pain. First, there was Tracy's pain and the pain to come with the multiple surgeries lying in her future. Tracy was not always in pain, but she was in pain whenever she was moved or left in one position for too long. Pain was thus a regular, if not incessant, part of her life.

Then there was the pain of the parents. In affirming the judge's refusal at Latimer's first trial to leave the defence of necessity with the jury, the Saskatchewan Court of Appeal found that there was an option to killing her: that if Latimer "could no longer bear the burden of caring for Tracy, there was the real prospect of permanent placement in a group home." ${ }^{61}$ If he had wished to be rid of Tracy because she was a burden, would he not have pursued that option? But for Latimer, group home placement was no option because, although it would have hidden her pain from him, the pain would still be there.

Last October an interview with the Latimers by Hana Gartner was broadcast on CBC-TV. ${ }^{62}$ When Gartner told Latimer that "killing is not an act of love," Latimer bristled and responded: "Is mutilating someone an act of love? Is cutting a feeding tube into someone an act of love? How many medical intrusions which carry a cost of great pain can you inflict on someone?" He insisted that Tracy lived in "constant pain and torture" and that he "just didn't want her to suffer anymore." And Laura Latimer said that, when she came home from church and found her daughter dead, she was happy for her. She too had lost hope, insisting to Gartner that "Bob did the right thing for Tracy."

When asked by the defence counsel at the first trial about the parental caretaking for Tracy, Dr. Dzus responded, "I had no concerns about the way Tracy was being cared for." She then answered "no" to the question, "Did you ever perceive that they had anything but her best interests at heart?" ${ }^{63}$ Still, the Latimers can be faulted for equating surgery with torture and mutilation. Feeding Tracy by hand was an ordeal that a feeding tube would have obviated. Its insertion is uncomplicated and it would have made life easier for both Tracy and her parents. The proposed hip surgery was more onerous, but it held the promise of long term relief from painful muscle tension, albeit at the cost of unavoidable post-surgical pain. ${ }^{64}$ However, it was not simply the spectre of the hip operation that prompted Latimer to take Tracy's life. She had already

That intuition is of course what prompted the jury and judge at Latimer's second trial to reject the life sentence.

Supra note 11 at 643.

The News Magazine (19 October 1998).

Supra note 45 at 191.

Ibid. at 188. 
undergone three major surgeries and still faced a lifetime of medical interventions that held scant promise of making her life relatively pain-free.

In his confession to the police, Latimer stressed that his priority was to end her pain, and the Crown presented no evidence to dispute that contention. At the second trial, seventeen Crown witnesses acknowledged that pain was part of Tracy's life although they varied in their impressions of the extent of that pain. ${ }^{65}$ But according to her father, anyone who was not with her day after day could not grasp the extent of her suffering. In any event, I do not believe that Latimer acted solely to end her pain, although he may think that. For how can one parcel out his grieving for her and his grieving for himself and his wife because of her pain and its effect upon them? In other words, her hurt was his hurt and her pain was his pain. He cared for and loved her for twelve years, and although his critics say that he killed her because his love ran out, I very much doubt that. Every day there are families who sigh with regret mingled with relief when a suffering relative dies, and that surely is no indication of an absence of caring and loving. For love is compatible with the belief that death for another is a welcome release.

Latimer may have run out of the stamina and emotional resources necessary to cope year after year with a severely disabled child, but his love for her did not run out. ${ }^{66}$ If he had not loved her, then her pain would not have been his pain and he would not have felt compelled to end her life. Again, this is not to excuse the crime, but it surely helps us to understand it.

Last but not least, there is the pain that the case has inflicted upon the disabled community. To begin with, the severely afflicted like David Martin can relate to Tracy Latimer in a way that I cannot, because they too have experienced the hardship of longterm disability. As I heard Catherine Frazee, onetime chairperson of the Ontario Human Rights Commission and a lifelong quadriplegic, say about Tracy, "[s]he was a member of our tribe."167 I confess that my initial reaction was to dismiss her comment as rhetoric. After all, Ms. Frazee has a sparkling intellect whereas Tracy had the mental capacity of an infant, and to me that is a world of difference. Upon reflection, though, I believe that what she meant was that whatever the extent of their handicap, those who are severely disabled are in a sense outsiders. They are perceived as different from the rest of us, and all too many of us regard them with irrational dread and fear - and the sentiment that they would be better off dead, both for their own benefit and that of society. If the disabled were fully integrated into society - treated as full human beings who may be different from but no better or worse than the nondisabled - then

Supra note 11.

In his decision, Noble J. stated: "The evidence reveals the enormity of their task (the Latimers) in caring for Tracy on a day-to-day basis but establishes that Mr. Latimer shared in providing for her needs." Supra note 12 at 15.

I heard that comment from Ms. Frazee when she spoke as a distinguished visitor to the University of Manitoba Law Faculty on 28 January 1998. Before her presentation, she graciously met me in my office for a long private chat. Although we acknowledged our disagreement on Latimer, we got along fine. She is a gracious, charming, witty, and sensitive person with a brilliant and incisive mind, all of which sparkled forth when she spoke to faculty and students. 
Ms. Frazee might not feel that special kinship with Tracy Latimer. But that, alas, is not the way of the world, and they are indeed of the same tribe.

When Noble J. handed down his two year sentence, voices within the disabled community protested that it cheapened the lives of the disabled and amounted to statesanctioned discrimination against our most vulnerable citizens. He was accused of sending the message that Latimer deserved a reduced sentence because Tracy's worth as a person had been diminished by her disability. In her op-ed piece in the National Post, Judith Snow contends that those who support leniency for Latimer by stressing his daughter's handicaps denigrate the lives of the severely disabled like herself. They seem to be saying to her that those like Tracy are really better off dead. As she put it: "[n]ow, on top of my physical disabilities, I have to deal with a public that wonders why I want to live or even if I should be allowed to.... Save me from one thing and one thing alone. Save me from all those who would have me dead for my own good."68

Ms. Snow's is but one in a chorus of voices to respond in anger to Noble J. As reported in The Globe and Mail, "representatives of national disability groups decried the ruling as a travesty that amounts to 'open season' on vulnerable people." ${ }^{69}$ Many of the disabled have commented that the ruling has given them reason to fear for their own lives - that their caregivers may take it as the signal that if they discharge their burden as did Robert Latimer, then the law will exact a cheap price.

Some of the most passionate critics of Robert Latimer have been parents of disabled children. A mother who attended the first trial expressed her outrage to reporters during a recess: "Do you know what it's like to hear that killing your child is defined as an act of love when love is what it takes to wake up with new energy every morning to give care and comfort to a child who is absolutely dependent on her parents." 70 A clamour of parental voices reacted with vehemence to the two year sentence. Typical was the response of a prominent Winnipeg lawyer whose child has cerebral palsy: "It's a sick society when killing is compassionate and punishment for killing is considered cruel."71

However, not all such parents have turned a stern face to Robert Latimer. A Toronto mother of a severely disabled seven-year-old, who she says "teaches us about the essence of being human," wrote Latimer a letter, saying: "I believe your act was genuinely motivated by love...you, however imperfect, are not a murderer." 72 And a Vancouver mother of a severely disabled 18-year-old has also expressed compassion for Latimer: "I know what it is like to see your child in pain and not be able to do anything. It's the worst thing that can happen to a human being." ${ }^{73}$ And there have been many others to that effect quoted in the media. A few months ago I had a

Supra note 28.

The Globe and Mail (2 December 1997) A8.

Supra note 44.

Radio interview, CJOB (2 December 1997).

Supra note 44 at 16.

Ibid. 
conversation with a pediatric orthopaedic surgeon, many of whose patients have cerebral palsy. He told me that he has discussed the Latimer case with many of the parents, all of whom said that, although they could not excuse what he did, they could understand the desperation and heartache that drove him to it and consequently did not believe that he should be sentenced as a murderer.

Still, what remains is the anger expressed by so many in the disabled community over the death of Tracy Latimer. Their feelings have not abated over the years, no doubt exacerbated by the fact that Latimer steadfastly insists that he did the right thing. For example, he has been called the "remorseless murderer" of "a child who had every right to absolutely trust him." is simply one way of saying that he still believes he did the right thing. We will no doubt hear much of the rhetoric of remorseless killing and barnyard ethics when the case is argued before the Supreme Court; although I may deplore it, I recognize that it is grounded in the pain that Robert Latimer has brought to the disabled community. ${ }^{75}$

\section{Presumptive, not Mandatory, Sentencing}

Although I respectfully differ from the views of David Martin and others on the Latimer sentence, I do not seek to vindicate or excuse him for killing his daughter. The law cannot pronounce him guiltless of the deed because no one can be allowed to kill another in accordance with the belief that the other is better off dead. That is to play God and therefore is not within the purview of us fallible mortal beings. ${ }^{76}$ But still, as Professor Dickens has pointed out, the springs to action of a Clifford Olson and a Robert Latimer are not of the same order.

Much to the same effect was the 1995 report of the Special Senate Committee on Euthanasia and Assisted Suicide. ${ }^{77}$ There was no consensus on the issue of

J. Derksen, "Latimer Leniency Wrong Message" Winnipeg Free Press (2 December 1997) A13. Once again, I acknowledge that the hostility toward Latimer is not confined to members of the disabled community, albeit my focus has been upon that community.

As I say later in the context of mandatory minimum sentencing, I abhor what I call No-Never rules (rules that make no exceptions). For that reason, I would not go so far as to say that a defence of necessity should never be allowed in a case of non-voluntary euthanasia. I do think, however, that the circumstances would have to be extraordinarily compelling to satisfy the test for necessity laid down by the Supreme Court in the case of $R$. v. Perka (1984), 14 C.C.C.(3d) 385 [hereinafter Perka]. Although I have noted my quarrel with the rejection of the defence in the Latimer case by the Saskatchewan Court of Appeal (that Latimer could have left her in a group home if he could not bear to witness her pain), I am not satisfied that he could meet the stringent test laid down in Perka by Dickson J. (as he then was). As he there stated, the issue is "whether the wrongful act was truly the only realistic reaction open to the actor or whether he was in fact making ... a choice" (ibid. at 400). Furthermore, the act must be "inevitable, unavoidable, and afford no reasonable opportunity for an alternative course of action that does not involve a breach of the law" (ibid. at 406). These are indeed formidable obstacles to the defence which I do not believe that Latimer could overcome. I would frankly be more comfortable with the defence when there was the informed consent of the deceased (i.e. a case of voluntary euthanasia or assisted suicide).

Supra note 3. 
legalization, the Committee recommending the retention of the prohibition against voluntary euthanasia by a 6-3 margin and that against assisted suicide by a 5-4 margin. On the other hand, all nine considered that the mandatory minimum sentencing provisions for murder in the Criminal Code were inappropriate in cases of compassionate homicide. The Committee accordingly proposed that "the Criminal Code be amended to provide for a less severe penalty in cases where there is an essential element of compassion or mercy."78 It suggested that Parliament enact either a third category of murder or a separate offence of compassionate homicide, and that either way there be no mandatory minimum sentence. ${ }^{79}$ In an appendix on "Assisted Suicide and Euthanasia in Foreign Jurisdictions," the Report noted the provision for a mercykilling defence in such civil law jurisdictions as Germany, Sweden, and Switzerland (the effect of which is to reduce murder to manslaughter). ${ }^{80}$

Disability rights groups have been quick to brand the Committee's proposed amendment as a licence for the mass killing of the disabled. That has not been the experience in the jurisdictions that recognize a mercy-killing defence, and there is no reason to suspect that such a dire prediction would come to pass in Canada. The Committee acknowledged that it was prompted to recommend a special category of compassionate homicide only because of the mandatory minimum sentencing scheme for murder. ${ }^{81}$ In other words, if there were no mandatory sentencing, then there would be no need to consider a mercy-killing defence. I too would have no quarrel with the stigma of a murder conviction attaching to Robert Latimer if it were not coupled with a mandatory life sentence. If the law wishes to declare that the killing of a disabled person for compassionate reasons is no less murder then the intentional killing of a teller by a bank robber, then so be it. So far so good.

But the other side of crime is punishment; as the old song says about love and marriage, you can't have one without the other. Thus, the labelling of the crime is only half the matter. What remains is the ascription of the punishment to fit the crime. But even that is not enough because a judge cannot assign the fitting punishment for an offender by focusing solely upon the label that the law attaches to the act itself. That is why penalty provisions grant such wide sentencing ranges.

The latitude granted the judiciary thus allows for the fashioning of a punishment that does not simply fit the crime, as Gilbert and Sullivan would have it, but a punishment that fits both the crime and the criminal. If all that counted was to prove the requisite elements of criminal responsibility - actus reus and mens rea - then every crime would have a fixed sentence (perhaps accompanied by a scale of increased penalties for repeat offenders). But that is not the way it is, and that is because there is more to producing a complete picture of the crime and the criminal than proving the requisite act and state of mind. The crime takes its coloration from the criminal, and therefore

lbid.

Ibid. at A-149-173.

Ibid. at 88. 
a multitude of factors - including the motive that triggered the crime - are integral to the sentencing process.

The Latimer case is of course different, and that is because mandatory minimum sentencing for murder enshrines the No-Never Rule. Mandatory minimum sentencing is a political statement of zero tolerance, and hence its sway must be all encompassing; that never - No! Never! - can the judge free herself from the shackles of the rule. But such a rule is objectionable because it rejects every principle of justice, all of which in one way or another focus upon the offender. But the No-Never rule is blinkered; it sees the offence to the exclusion of the offender. ${ }^{82}$

To my mind it is a principle of fundamental justice that the penalty not be set in advance; that justice is not served by a sentencing scheme that fails to recognize that no two crimes and no two criminals are identical. The simple reason is that people, unlike the grains in a bin, are not fungible. I believe, therefore, that mandatory minimum sentencing for murder is in violation of s. 7 of the Charter, and that it cannot be saved by $s .1$ because there is no credible evidence that the severity of punishment - even the death penalty — is a deterrent to murder. Mandatory minimum sentencing for murder may give the public a false sense of security at home and on the street, but surely the public need for a security blanket is insufficient warrant for Latimer's life sentence.

There is a reasonable alternative to mandatory minimum sentencing for murder, which I call presumptive sentencing. The current sentences would remain in place life sentence for first-degree murder with no parole eligibility for twenty-five years and life sentence for second-degree murder with parole eligibility set between ten and twenty-five years. But, then, the law would allow the judge to reduce the sentence for either category of murder on the grounds of compelling mitigating circumstances. And there would be no minimum mandatory sentence of imprisonment. ${ }^{83}$ I would even

Mandatory minimum sentencing is not confined to murder. Section 85 of the Criminal Code using a firearm in commission of offences - stipulates a minimum sentence of one year in prison for a first offender and three years for a repeat offender. Section 255 provides minimum penalties for impaired driving and refusal to provide breath or blood samples (which offences are found in ss. 253-4). The minimums are: a $\$ 300$ fine for a first offence; fourteen days in jail for a second offence; and ninety days for a subsequent offence. And s. 202 - betting, pool-selling, bookmaking, etc. - provides minimum penalties for repeat offenders: fourteen days for a second offence and three months for each subsequent offence. A discussion of these provisions is beyond the scope of this paper, but suffice it to say that in principle I oppose mandatory minimum sentencing whatever the offence.

I have borrowed the term "presumptive sentence" from Fair and Certain Punishment, The Report of the Twentieth Century Fund Task Force on Criminal Sentencing (New York: McGraw-Hill Book Company, 1976) at 19. The Task Force recommended that a precise sentence - the presumptive sentence - be allotted for every crime, but that there be room "to adapt the sentence reasonably to the particular circumstances of the crime and the peculiar characteristics of the criminal." (Ibid.) If there were no specific mitigating or aggravating factors, then the offender would receive the presumptive sentence. But if the former were proved, then the sentence would be decreased, and likewise if the latter were proven then it would be increased. My proposal is the same when it comes to first-degree murder, because that has a precise sentence (so aggravating circumstances might mean the cancelling of parole eligibility - that life means life). It is different 
stipulate that the burden of proof rest with the defence to show why the presumptive sentence in place should be waived in the particular case. ${ }^{84}$

As it now stands, however, the shackles of s. 745(c) condemn Latimer to a minimum ten year sentence. ${ }^{85}$ Although the Saskatchewan Court of Appeal paid short shrift to Noble J.'s extraordinary sentence, what survives is the fundamental truth that he and the jury grasped - that because the crime and the criminal are bound together, the fitting punishment cannot be measured against the act alone. The question now, of course, is whether the Supreme Court will leave it be. I hope not and I say that because Gilbert and Sullivan only got it half right. It is not enough that the punishment should fit the crime. It should also fit the criminal.

\section{FINAL WORD}

Although disability rights groups have been at the forefront of the opposition to leniency for Robert Latimer, they have their allies outside their community. Similarly, support for Latimer has come from within and without the disabled community, although not to my knowledge from any organization representing the disabled. However, I have chosen to focus upon the anti-Latimer voices within the disabled community for two reasons. First, because Tracy Latimer was of their community, they bring a special perspective to the case that must be heard. There is a bond that ties those like David Martin and Catherine Frazee to those who, alas, like Tracy cannot speak for themselves. And I readily acknowledge that they cannot be faulted for expressing anger - nay, outrage - when a member of their tribe is killed by her natural protector.

Second, my contrary view on the Latimer sentence has challenged me to explain a stance opposed by spokespersons for that community of the stature of David Martin and Catherine Frazee. I believe that in my teaching and writing I have established credentials as an advocate for the disabled, and I am frankly pained that we stand poles apart over the fate of Robert Latimer.

Yet, however understandable their position, what drives it goes well beyond the facts of the case and the question whether "murderer" is the appropriate label for a so-called mercy-killer. As I have mentioned, David Martin has told me that the Latimer case cannot be isolated from a multitude of issues that impact upon the disabled. As he has

for second-degree murder which has a ten to twenty-five year penalty range. In that case, aggravating and mitigating circumstances would mean going above and below that range.

My reasonable proposal is arguably not a viable one, given the public's infatuation with the mandatory life sentence for murder. I would imagine that a massive wave of public protest would greet any attempt by Parliament to replace it with a presumptive sentencing scheme. But, then, Parliament had the will to abolish capital punishment when the public overwhelmingly supported its retention. Still, I would be surprised (albeit happily so) if mandatory sentencing for murder did not remain a permanent fixture.

ss It is true that, in Latimer's case, the judge's hands are not fully shackled, as latitude is allowed along the ten to twenty-five scale stipulated for second-degree murder. But shackles are still shackles even if lightly loosened. 
said, they "are all of a piece," and that is why I devoted the first part of this paper to a review, however cursory, of the pieces that fit together.

Consider, for example, the reaction in disability circles to the Winnipeg case of 80year-old Bert Doerksen, currently facing a charge of assisted suicide stemming from his wife's death from carbon monoxide poisoning in the family garage. The couple had been married for 59 years, and Mrs. Doerksen was afflicted with numerous ailments, including intractable and severe arthritic pain which the Winnipeg Pain Clinic was unable to relieve. She had repeatedly expressed the wish to die, and the Crown's position is that her husband helped her to that end by sealing the garage door and a car window with duct tape. Friends and neighbours have described Doerksen as a devoted and loving husband, and his three children have expressed their outrage that proceedings were not stayed. The Crown is proceeding even though Doerksen is afflicted with cancer of the lymph nodes and bone marrow and may not live to go to trial. ${ }^{86}$

According to the Winnipeg Free Press, "fear of a public outcry from special interest groups representing Manitoba's disabled community may have prompted the Crown's office to pursue the charge." ${ }^{87}$ Whether that is true or not, what is true is that a number of spokespersons for such groups had publicly insisted that the case go to trial. Yet, this is the same community that has repeatedly stressed that Latimer must be condemned because his daughter did not ask to be killed. But the Doerksen case is of course different. Since the very basis of the Crown's case is that Susan Doerksen asked for help to kill herself, why this insistence that her husband be prosecuted? I suggest that the reason is - and I am again borrowing a phrase from David Martin - that the cases of Latimer and Doerksen cases are "of a piece."

In one sense, they may be viewed as cases in which the accused is faulted for seeing death as the only acceptable solution to pain, and from that standpoint it is beside the point whether or not the act was consented to. But there is also a sense in which these two cases are of the same piece as the issues I have briefly canvassed: assisted suicide and voluntary euthanasia, medical futility and the physician's refusal to provide treatment, and the patient's right to refuse life-prolonging treatment. They are all of a piece because each in its own fashion can substitute for a societal commitment to the welfare of the disabled. If this is how one sees it, then the deaths of Tracy Latimer and Susan Doerksen are not so different because they both show how the lives of the disabled are marginalized.

For the physically disabled themselves, the Latimer case strikes a particularly sensitive chord; it is a reminder of the stresses and burdens that can impact upon the family when it assumes the care-giving role. If Latimer could be driven to kill his daughter, can they remain reassured that those upon whom they are dependent will always be there for them? And can their families, however selfless their devotion, 
remain confident that they will never waver, that hidden resentments that may surface only in their dreams will never lead them down Latimer's road?

The disabled certainly have reason to question whether our perennially underfunded health care and social services systems can sustain a commitment to their well-being. As costs spiral upward, fuelled by the impact of a rapidly aging population, it is not paranoia to fear that the helping hand will not always be there. Discrimination in education, employment and housing, and the sentiment of all too many Canadians that the disabled should be kept out of sight and mind can only add to the sense of insecurity that pervades the disabled community. It is a community that feels itself under siege, a feeling heightened by the widespread public support for Latimer; and, in the result, Latimer has come to serve as a visible outlet for its pent-up frustration and fear.

I am not painting Latimer as a scapegoat for society's deficiencies; he did, after all, kill his daughter. Rather I am suggesting that a community that feels itself marginalized will not have the patience to temper its grief at the killing of one of its own with an effort to understand what could have driven a loving father - the devoted caretaker of his daughter for twelve years - to act on the belief that her life was no longer worth fighting for. It is easier to assume the worst about him, to label him as a remorseless murderer, as a practitioner of "barnyard ethics" who must be locked up for at least ten years.

After the second conviction (but before Noble J. passed sentence), The Globe and Mail published a letter from Dave Graham, a Toronto resident with cerebral palsy who lauded the guilty verdict and added: "I would encourage those who are siding in the Latimer direction to consider placing their efforts toward political action against government cutbacks to social services which support parents of children with disabilities, as well as the adults we become if we are not murdered." ${ }^{88} \mathrm{Mr}$. Graham is surely right that it is the political arena that holds the key to the welfare of the disabled and their caregivers. In that regard, there is an historical spectre that serves as a constant reminder of what can happen when a society abandons its respect and compassion for its most vulnerable citizens. I am referring to the fate of the disabled in Nazi Germany. There are no precise figures as to how many disabled Germans were murdered pursuant to Hitler's so-called euthanasia program, although 70,000 were known to have been killed in its first two years of operation (1939-41) ${ }^{89}$ They were killed for two reasons: because expenditures on their behalf were considered a waste of money, and because their mere existence was incompatible with the creation of a master race of goose-stepping blond supermen.

D. Graham, "Letter to Editors" The Globe and Mail (8 November 1997) D7. On the same page was a letter from the grieving parents of a ten-year-old who had died a lingering death from cancer and who expressed their sympathy for Latimer with the heated comment that: "The self-righteous representatives of the disabled community shame themselves with their cruel rhetoric." 
Canada at the millennium is worlds away from Nazi Germany, but who can guarantee that one of the incentives to Hitler's war against the disabled - the costsaving factor - will never produce a Canadian euthanasia program? If that ever happens, it will not begin, as it did in Germany in 1939, in a flurry of bureaucratic activity leading to death by gas, lethal injection, and even shooting. I certainly do not dismiss the fear of David Martin and others that legalization of voluntary euthanasia and assisted suicide could translate into the pressured duty to die. But I think it more likely that, if we head down that bitter slope, it will be a barely perceptible slide in which death occurs not by violence but by neglect. It will not be sudden death but death by inches, and its resemblance to natural death will help to mask the insidiousness of it all. That is the spectre that should haunt us all and that should keep us on guard against a declining commitment to health care and social services for the disabled. That is where the threat lies, not from the solitary act of the farmer from Wilkie, Saskatchewan.

When Noble J. handed down his two year sentence, Dr. Raffath Sayeed, president of the Canadian Association for Community Living responded: "I'm in shock. This is an absolute travesty of justice." ${ }^{190}$ But the life sentence that he deems fitting cannot be justified by any principle of punishment, and, furthermore, I do not see how it will benefit the disability rights movement. Fortunately, that movement has produced eloquent and able advocates such as David Martin and Catherine Frazee to promote the interests of the disabled. But they and their colleagues cannot do it alone, for something more is required to ensure that the disabled amongst us are treasured and helped to make their way in life. That something more must come from the society at large a society that comes to know that being human means that lending a helping hand to our fellow citizens in distress is the right thing to do. Thus, the political arena may hold the key, but it will take an enlightened public to see that it opens the door. Noble J. was being human when he extended the hand of leniency to Robert Latimer (and by extension to his family) in recognition of the distress, love, and pain that had driven him to take his daughter's life. If the Supreme Court sees it his way, I hope that the sizeable majority of Canadians who would applaud that result learn that being human is a virtue - and that there is no better way to express it than by cherishing the disabled amongst us. They are our brothers and sisters, and all that marks us - the non-disabled - as different is that we have not been stricken by the cruel hand of fate. But one never knows but that tomorrow may visit that fate upon any of us, and if it happens who will be there to lend a helping hand? 